\title{
Russian science journalism: the past and the future
}

\author{
Viola Egikova* \\ Russian Association for Science Writers and Journalists INTELLECT, Horoshovskoe shosse 50-98, 123007 Moscow, Russia
}

\begin{abstract}
Russia has a rich history of scientific discovery. Before the communist revolution, newspapers published articles on scientific topics, and public lectures on science were popular. Under the Soviet regime, science journalism turned into a refuge for journalists who did not want to write communist propaganda, but the range of topics was restricted by harsh censorship. Today's Russia faces the choice of what the future of science journalism should be.
\end{abstract}

KEY WORDS: Science journalism · Russia $\cdot$ Soviet Union

Resale or republication not permitted without written consent of the publisher

\section{INTRODUCTION}

The new generation of news consumers in Russia, created by today's mass media, want to read about the 'memory of water' and hear stories about how our existence will be totally destroyed by a black hole generated by 'crazy physicists' in the Large Hadron Collider. I do not know whether the same topics are fashionable in other countries today, but in my country you may read about them in newspapers and on the internet, see them on TV and listen to them on the radio. A story about 'water memory' even earned an award in a recent competition for TV shows in Russia. They called it a 'popular science film', and it received great interest from the public. I am afraid that a very informative and modest story about the history of science in Russia, which is being shown on the channel 'Culture', has a smaller audience.

Why does the public prefer junk science? Why is it so popular in the Russian mass media? One could argue that this is simultaneously a positive and a negative situation. Positive because, at last, we have a freedom for our mass media to say what they want, which was impossible in Russia and the Soviet Union for decades. Negative because freedom for the media does not mean that journalists have no responsibility when giving people false information just to raise their interest and for the profit of the media owner. To understand this situation, I will provide a brief overview of the history of Russian science journalism and describe some of my own experiences as well as insights gained from exchanging ideas with my journalist colleagues.

\section{THE PAST}

\section{A great myth}

The history of Russian science and science journalism is still not fully interpreted. This is true both outside and inside of the country. Even in this history, we often prefer myths to reality. We usually insist that there is a special 'Russian way' of understanding things. Each nation has its own culture and mentality. However, nobody likes to discover the skeletons in their closet. The only difference is that the Russian society was closed off for many years, which helped to create a certain kind of mythology.

In his very last book, which was published after he passed away, academician Dmitry Lihachev observed that nobody has ever seen such a huge myth affecting a whole nation. He was referring to the myth about a poor and illiterate Russia that was very behind compared to the educated rest of Europe. According to Peter the Great, the development of Russia started just after his reforms, and it was he who brought Russia into the European community. However, science in Russia has a longer history - it did not only start to develop after the reforms by Peter the Great, but the tsar used the myth of an undeveloped country to create his empire.

Later on, communists continued to build on this myth. They only changed the time of the start of the development of Russia: according to communists, education, intelligence and development started after they came into power. You will read that Russia was back- 
ward, undeveloped, uneducated, and that only communists could bring positive change to the country.

Until 1914, before the First World War, Russia was among the most powerful countries in Europe, having not only great literature and art, but very good science, universities, science museums and science popular media. There was a strong tradition of public lectures in the Politechnical Museum, the Art Museum and at different universities, which had a great impact on the media. When looking through archival material, I was surprised to find a large number of pieces in newspapers and magazines, documenting a huge interest in science. But there is no historical research on the popular science media that existed before the revolution in 1917.

\section{Science journalism in the Soviet Union}

After 1917, a new page was turned for Russian science journalism. Among the first actions of the Soviets was the abolishment of the traditional media. Instead, new media under strong political control were established. This was the end of free journalism for decades. After the revolution and before the 1960s, science journalism was virtually absent from Soviet media. Many scientists left Russia after the revolution and continued their research in other countries. Among these were Igor Sikorsky (the 'father' of American airplanes), Vladimir Zvorykin (the 'father' of American television), George Gamow, Otto Struve, Alexander Procofieff de Seversky and others. If you check the number of American Nobel Prize Winners or other well-known scientists, you see that many of them have their roots in Russia. The same holds true today. Allegedly, maybe half or even two-thirds of the scientists in some of the biggest international corporations are of Russian origin.

Russia began to lose scientists in 1917, before the 'iron curtain' closed. This brain-drain was never reflected in the Soviet media before the mid-1980s. Nobody was allowed to write about it. This was also the case for the fate of those scientists who did not leave the country when it was still possible to emigrate. Starting in the late 1920 s, many millions of soviet people were arrested and killed in prison, scientists among them. Russia was losing more scientists.

If you read the biography of scientists who lived during that period, you will realize that almost every one of them was arrested and only a few were not shot. Some were lucky to emigrate before being arrested, such as the Nobel Prize winning economist Wassily Leontief. Others, such as the biologists Vasily Parin and Nikolai Vavilov, were arrested as 'American spies' - Parin was 'guilty' of having professional con- tacts with foreign colleagues. Nikolai Vavilov died in prison. His brother, the physicist Sergey Vavilov, was President of the Academy of Sciences of the USSR during that period, but he could not help - he could not even try. The great geneticist Nikolai Koltsov died being called an 'enemy of the people'. Alexander Chizhevsky was in exile in Karaganda until the late 1950s. The leading soviet rocket scientist Sergey Korolyov was working out of prison for many years. There was even a word for scientists and engineers who worked under arrest-'sharashka', which refers to a special prison for scientists doing their research in captivity. It is still used in the Russian language today.

Of course there was nothing about that in the Soviet media, or the journalists would have been arrested too-but they were arrested and shot even if they were positive towards the state system. Only after the so-called 'perestroika' could books and articles about scientists who were repressed during Stalin's time be published. Finally, the archives were opened and journalists could find out about the processes against scientists. For example, a terrible process against biologists happened after 1948, which stopped the development of biology in the Soviet Union. Genetics, microbiology, psychology, sociology and many other fields of science were labelled 'ideologically wrong' and were forbidden in the country. It was the end for scientists who could not continue their research. Only nuclear physicists had some amount of freedom because there was a great need for their science. However, even in that situation, the well-known physicist Piotr Kapitha was a prisoner in his own 'dacha'.

Since 1991, several books have been published with the same word in their title-'repressed': 'The repressed ethnography', 'The repressed geology', 'The repressed science' and so on. Nowadays, there are special sites on the internet with the names of thousands of scientists and students who were killed, arrested, or repressed during Stalin's regime. These stories could only be told after 'perestroika' in the 1980s. For example, I could not publish an article about the situation in the Institute for Genetics until the mid1980s. At that time, it was one among the first articles about the history of genetics in the Soviet Union. It is hard to believe today that one could write an article about the repression of studies on genetics and be among the first after almost 40 years! It seems now that we always knew about this and could always describe it in our writing. It is very difficult to imagine how limited the subjects and topics were for science journalism for many years.

Soviet science journalism was born at the beginning of the 1960s, when the Soviet Union began to move from the Stalinist system towards being a more open 
country. It was not a really open society of course, but there was a change in culture.

It was a period of exciting news about space and technology. Science was respected in the country, articles about science and scientists were in demand. Dozens of journalists and writers began to write about science. The articles were mostly devoted to space and technologies, less to medicine. There were only a few other fields of science one could touch now, but even with that limited number of topics it was a new way for journalism. And it was a way to separate from Soviet propaganda. Science journalism became a sort of refuge for journalists who did not want to write about communist ideology.

We have wonderful examples of popular science articles from the 1960s and the 1970s. When you read these articles, you understand: science journalists were mostly devoted to their branch of journalism. They say it was a brilliant era of science journalism during the Soviet period. And that is true. However, it is also a new myth, because even brilliant examples of Soviet science journalism were still those pieces that had been permitted. Each science journalist could work only under strong censorship, or the article would never have been published.

Yes, science journalism was a refuge. But the borders of that refuge were very strong. I have been a science journalist since the mid-1970s and I know what it is to be under censorship. No article was ever published without the censor's stamp of approval. He had to check not only the names and cities that were allowed to be mentioned in the media, but the topics as well - there were some topics that were not recommended for publishing. However, this was official censorship at the time.

We also had unofficial censorship. One day, my boss told me that the editor-in-chief of the newspaper I worked for was very disappointed with what I wrote. He asked whether I did not understand about whose names I used in my articles. I really did not know what he meant because I tried to write about very interesting scientists. So my boss explained: the editor-in-chief knew that Soviet newspapers could not publish too many Jewish names. There were no official rules about it, these rules were hidden, but journalists had to know them anyway.

In July 1994, I published a newspaper article after a phone call from Simon Ilizarov, then senior researcher at the Vavilov Institute for the History of Science and Technology of the Russian Academy of Sciences. Ilizarov told me: 'I found a very interesting document in the archive of the Communist Central Committee.' I asked him to bring that document, which was a secret message that had been sent to the Central Committee of the communist party in May 1958. We immediately published it with Simon Ilizarov's comments. The document had been written by a person who worked as an instructor in one of the local party committees, and the subject was the approaching elections in the Academy of Sciences. This person wrote that 'a group of noncommunist scientists' were trying to elect some 'wrong persons' into the Academy. Among these 'enemies' in the group were the Nobel Prizewinning physicists Igor Tamm and Leo Landau, and Lev Artsimovich. The scientists who were not supposed to be elected, according to that secret message, included the Russian physicist Vitaly Ginzburg, who was awarded the Nobel Prize a few years ago (2003). He and some others were 'wrong' because they were non-communist-and Jewish.

That message included recommendations to the Academy about who could be elected and who should not be. We looked in the archives from that period and found that the Academy kept its integrity: Vitaly Ginzburg and other 'wrong' scientists were elected. It was 1958, Stalin was dead, his regime had collapsed and it was possible to have some distance from the 'recommendations from officials'. However, this was an exception.

Science and science journalism cannot exist without freedom. The Austrian-British philosopher Popper (1959) said: 'You cannot have a rational discussion with a man who prefers shooting you to being convinced by you'. According to Popper, '...truth itself is beyond human authority, there is no place for science if one cannot look for truth and has to follow just human authority. That is the end of science', he wrote. We could add: the same for science journalism.

\section{THE PRESENT - AND THE FUTURE}

Nowadays, there is nothing standing between us and good science journalism. No censorship. No official and unofficial rules to dictate the position of a journalist. Does this mean that science journalism could be at the top in today's Russia?

If somebody says this, it will be yet another myth. It will be a myth not because the circulation of science media is becoming lower every day-for example, circulation of the well-known magazine Nauka $i$ Zhisn (Science and Life) has sunk from over 3400000 in the 1980 s to only 40000 in the 2000 s and is probably even lower today. No subjects or names are forbidden for journalists today, there is no taboo, but still most of them prefer to write 'hot stories' about black holes in the Large Hadron Collider which will swallow up our poor planet. That's not science journalism, even if journalists are free to say whatever they want. 
When we had a totalitarian system, we dreamed of freedom. It is now becoming clear: freedom itself is important, but it is not enough for science journalism. What is the next step? Maybe we can move ahead with our education programs for journalists, with the study trips, competitions in science journalism, science cafés and science festivals we organize. But is this enough? There is a need to educate publishers as well to teach

Editorial responsibility: Stephanie Suhr-Sliester, Oldendorf/Luhe, Germany them about the importance of science, education, and a knowledgeable society. Will we achieve this?

The famous Russian novelist Anton Chekhov wrote that Russians prefer to dream; they are either in the past or in the future, but never in reality. Chekhov was a medical doctor and a very good diagnostician. I cannot say whether his words were a diagnosis or maybe just another sort of mythology.

Submitted: February 9, 2009; Accepted: February 11, 2009 Proofs received from author(s): April 8, 2009 